\title{
Determination of Matrix Metalloproteinases-9 in Egyptian Patients with Pulmonary Mycobacterium Tuberculosis
}

\author{
Samir A. El-Masry ${ }^{1}$, Mahmoud L. Khalil ${ }^{1}$, Mohamed K. Al-Badrawey ${ }^{2}$, \\ and Mohamed T. Shokhba ${ }^{3}$. \\ Molecular Biology Department, Genetic Engineering and Biotechnology Research \\ Institute, Minufiya University, Sadat City, Minufiya, Egypt ${ }^{1}$ \\ Chest Department, Faculty of Medicine, Mansoura University, Mansoura, Egypt ${ }^{2}$ \\ General health insurance organization, Ibn Sina polyclinic, El-Mahalla El-Kobra ${ }^{3}$
}

\begin{abstract}
Matrix metalloproteinases (MMPs) constitute a large family of enzymes that degrade extracellular matrix proteins (ECM). MMPs are implicated in tissue remodeling processes such as wound healing, and pregnancies. MMPs also participate in some pathological conditions such as cancer. Recent studies have shown that MMPs are induced by Mycobacterium tuberculosis (MTB) during pulmonary infection. The aim of the present study was to determine the Matrix Metalloproteinases-9 (MMP-9) levels in Egyptian patients with MTB compared to their levels in healthy control individuals. Forty six patients with MTB (group I) and forty three healthy volunteers (Group II) were included in the study. The concentrations of MMP-9 in the serum samples of the two groups were determined quantitatively by human MMP-9 enzymelinked immunoassay (ELISA) kit. The result showed that MMP-9 levels were significantly higher in MTB patients ( $p<0.0001$ ), compared to their levels in healthy control group. MMP-9 levels were increased with increasing the severity of the disease, since, their concentrations were significantly increased in complicated cases compared with uncomplicated cases $(p<0.0001)$. In conclusion, our study suggests that, the higher levels of MMP-9 in patients with tuberculosis may be due to overexpression by a variety of cells including mononuclear phagocytes and stimulated neutrophils. Also, MMP-9 levels were directly proportional with the severity of the disease. Their rising levels may be used as indicator of MTB activity.
\end{abstract}

\section{INTRODUCTION}

Mycobacterium tuberculosis (MTB) is a facultative intracellular, aerobic, acid-fast bacillus naturally pathogenic for human. Its virulence is related to its ability to survive and proliferate in mononuclear phagocytes. MTB reduces the bactericidal activity of macrophages by preventing the fusion of enzyme containing lysosomes with phagosomes containing the bacilli ${ }^{(\mathbf{1})}$.

The immune response is initiated when MTB arrives in the alveolar space where it encounters resident alveolar macrophages, after passing the protective mechanical barriers in the upper respiratory tract ${ }^{(\mathbf{1}, \mathbf{2})}$. This initial interaction between the alveolar macrophages and mycobacteria can result in destruction of the organism 
or persistence and replication of organism within the macrophage ${ }^{(3)}$.

In pulmonary tuberculosis, macrophages play a key role by releasing many kinds of proteases and cytokines, and by introducing a protective cellular immune response $\mathrm{e}^{(4)}$. Among the proteases secreted by macrophages, matrix metalloproteinases (MMPs) are particularly interesting, as these enzymes are able to degrade all extracellular matrices ${ }^{(5)}$. The proteolytic balance between MMPs and tissue inhibitors of metalloproteinases (TIMPs) is important not only in normal tissue remodeling, but also in various pathological conditions ${ }^{(\mathbf{6 - 9})}$. Proteolytic processes may play a role in the formation of pleural effusions by increasing vascular permeability, and therefore by facilitating fluid influx into the pleural space ${ }^{(\mathbf{1 0})}$.

The presence and enzymatic activities of MMPs and TIMPs have been identified in pleural effusions ${ }^{(11}$, 12). Tissue damage is a characteristic manifestation of infection by MTB. Proteolysis by macrophage-secreted proteases has been implicated in such destructive processes ${ }^{(\mathbf{1 3}, \mathbf{1 4})}$. In this regard, the proteolytic action of MMPs may be involved in the pathogenesis of tuberculosis, like many other diseases associated with tissue destruction. Several studies showed that macrophages release MMP-9 in response to MTB or its cellular components ${ }^{(15,16)}$. An in vivo study demonstrated the activation of MMP-2 and MMP-9 in the lungs of mice infected with MTB ${ }^{(17)}$. Chang et al. ${ }^{(18)}$ reported that the levels of MMP-9 were significantly higher in the broncho-alveolar fluid of patients with active cavitary tuberculosis. MMP-9 in patients with tuberculosis is not restricted to the site of infection, but it is also visible in circulation, as a result of stimulation of circulating leukocytes via cytokines released by activated macrophages.

The aim of the work, was to determine MMP-9 levels in Egyptian patients with MTB, using ELISA Kit, compared to their levels in healthy control individuals.

\section{SUBJECTS \& METHODS}

\section{All samples were collected after obtaining informed consent from the patients.}

a) Patients (group I). Forty six patients (41 males and 5 females) with a confirmed diagnosis of pulmonary TB from Mansoura, and El-mahalla El-kobra Chest Hospitals were selected for the study. The median age of the patients was 31 years (range: 20 to 62 years). TB patients group was classified into 33 complicated cases (15 with pleural effusion, 12 with empyema, and 6 with apical cavitation) and 13 uncomplicated cases.

b) Healthy volunteers (group II). Forty three subjects (31 males and 12 females) of non tuberculosis patients with no previous symptoms or disease were selected for the study. The median age of the volunteers was 32 years (range: 20 to 53 years). The healthy volunteers were documented by a general clinical 
examination and no respiratory symptoms were indicated.

\section{Bacteriological culture:}

Equal volumes of sputum samples were inoculated into tubes of Lowenstein-Jensen (L-J) medium with glycerol. The L-J tubes were then incubated for $6-8$ weeks at $35-37^{\circ} \mathrm{C}$, and inspected for growth at weekly intervals. Suspicious growth was subjected to Ziehl-Neelsen staining to confirm diagnosis. Negative culture was discarded after 8 weeks.

Ziehl-Neelsen staining: This technique was used for identification of Mycobacterium tuberculosis in sputum samples and bacteriological cultures according to the method described by Jenkins ${ }^{(\mathbf{1 9})}$.

Determination of serum MMP9: MMP-9 levels were determined in serum samples of pulmonary tuberculosis patients and healthy subjects using a commercial specific Enzyme-Linked Immunosorbent Assay (ELISA) kit provided by RayBiotech, Inc., Parkway Lane, Norcross Georgia, USA ${ }^{(\mathbf{2 0 - 2 2})}$. MMP-9 kit is used for the quantitative measurement of human MMP-9 pro and active forms in serum. This assay employs a mono clonal antibody specific for human MMP-9 coated on a 96-well plate. Assay was processed according to the manufacture's specifications.

Statistical analysis:

Results were expressed as mean \pm standard deviation (SD). Unpaired student "t" test and one-way ANOVA were performed using graph pad Instant version 3.00 for Windows 95, Graph pad software, San Diego California USA, to determine the significance. $\mathrm{P}$ value $<0.05$ is considered to be significant. Interactive dot diagram was performed using MedCalc version 11.1 for Windows XP, MedCalc Software, Broekstraat 52 B-9030 Mariakerke Belgium, with a horizontal line indicates the cut-off point with the best separation between the two groups.

\section{RESULTS}

The characteristics of the studied groups were summarized in table 1 . A total of 46 pulmonary TB patients and 43 healthy control individuals were included in the present study. The mean age of TB patients was $35.5 \pm$ 12.5 years, with a range between 20 62 years. The mean age of healthy control individuals was $32.4 \pm 8.9$ years, with a range between $20=53$ years. There was male predominance among the patients with TB, 41 males $(89.1 \%)$ versus 5 females (10.9\%), with a male-to-female ratio 8.2: 1 . In the healthy control subjects there were 31 (72.1\%) males versus 12 (27.9\%) females with a male-to-female ratio 2.6:1. there was a significance difference in the sex ratios of TB patients and healthy control group ( $\mathrm{p}$ $=0.05$ ). Regarding to cigarette smoking, $82.6 \%$ of TB patients were cigarette smokers in comparis on with non smoker healthy group which was statistically highly significant $(p=0.0003)$. All TB patients were sputum smear and culture positive for acid fast Bacilli. All patients presented with clinical and radiological pictures suspicious of pulmonary TB as unilateral and bilateral pulmonary infiltrates with lung cavities (table 1). 
Table 1: Characteristics of the studied groups:

\begin{tabular}{|l|l|l|}
\hline & Healthy volunteers & Tuberculosis patients \\
\hline Number & 43 & 46 \\
\hline Sex: female/ male & $12 / 31$ & $5 / 41$ \\
\hline Age (years) & $32.4 \pm 8.9$ & $35.5 \pm 12.5$ \\
\hline Smokers & --- & 38 \\
\hline Chest-x rays & --- & Cavities \& opacities are observed \\
\hline Bacteriological culture & 43 Negative & 46 Positive \\
\hline Z.N. staining for AFB & 43 Negative & 46 Positive \\
\hline MMP-9 levels (pg / ml) & & \\
Range & $270-3450$ & $3455-8500$ \\
Mean \pm SD & $2180.9 \pm 691.1$ & $6575.2 \pm 1323.4$ \\
\hline
\end{tabular}

\section{Determination of MMP-9:}

MMP-9 levels were measured in the serum samples of 46 tuberculous patients and 43 healthy volunteers, using MMP-9 ELISA Kit. The results showed that TB patients had higher MMP-9 levels (ranged from 3455 to $8500 \mathrm{pg} / \mathrm{ml}$ ), with the mean value of $6575.2 \pm 1323.4 \mathrm{pg} / \mathrm{ml}$, compared with its levels in healthy control group (ranged from 270 to $3450 \mathrm{pg} / \mathrm{ml}$ ) with the mean value of $2180.9 \pm 691.1 \mathrm{pg} / \mathrm{ml}$ (table 1 \& figure 1). Statistically, the levels of MMP-9 in TB patients were significantly higher than in healthy control group $(\mathrm{P}<0.0001)$ (table 1 and figure 1 and 2 ).

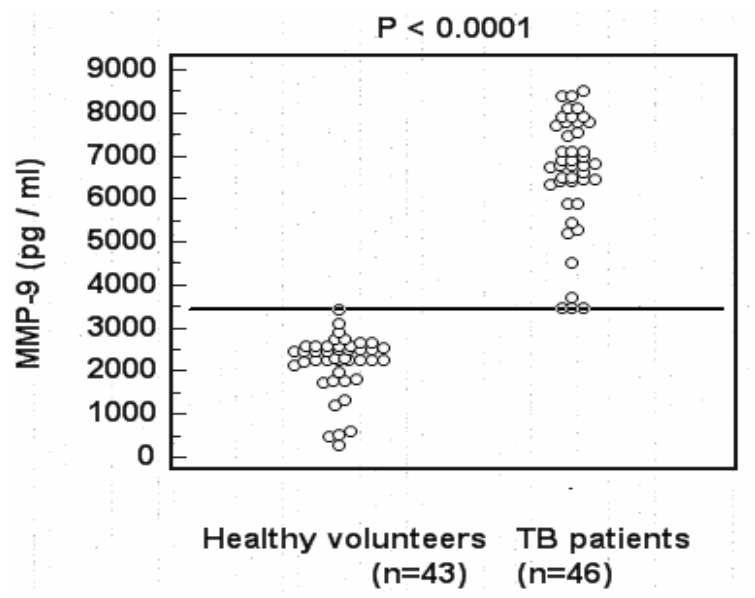

Fig. 1: distribution of the serum MMP-9 in 43 healthy volunteers and 46 TB patients. The horizontal line indicates the cut off point $(>3450)$. 


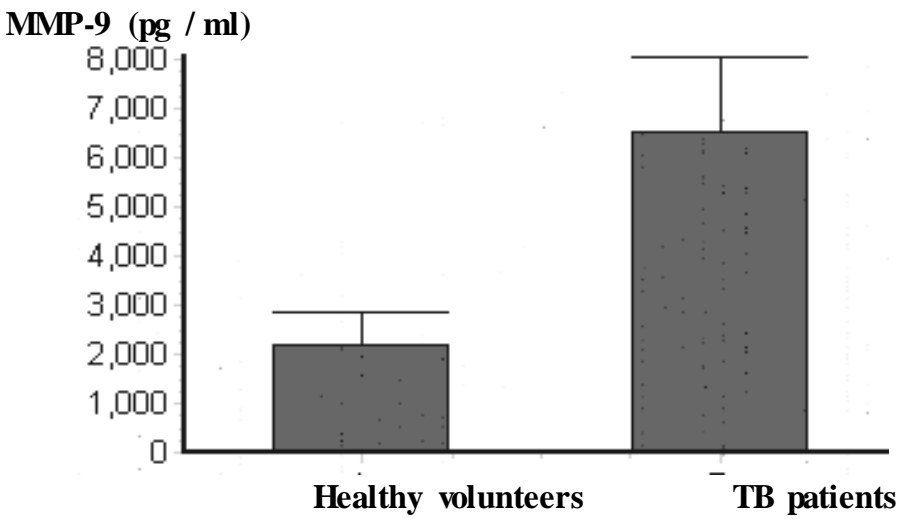

Fig. 2: MMP-9 levels in healthy volunteers and TB patients

\begin{abstract}
Also, we investigated whether MMP-9 levels in serum samples of tuberculous patients is of clinical significance or not. For this purpose the patients were classified according to the severity of the diseases into complicated and uncomplicated subgroups. Complicated patients subgroup was divided into 15 patients with pleural effusion with mean value of MMP-9 $(6625.5 \pm 199.17 \mathrm{pg} / \mathrm{ml})$, ranged from $6350-6900 \mathrm{pg} / \mathrm{ml}, 12$ patients with empyema with mean value of MMP-9 $(7819.2 \pm 424.1 \mathrm{pg} /$ $\mathrm{ml})$, ranged from $7100-8400 \mathrm{pg} / \mathrm{ml}$,
\end{abstract}

and 6 patients with apical cavitation with mean value of MMP-9 (7625 \pm $560.1 \mathrm{pg} / \mathrm{ml}$ ), ranged from 7000 $8500 \mathrm{pg} / \mathrm{ml}$. The complicated cases subdivisions had the highest mean value of MMP-9 compared to the mean value of MMP-9 (4884.5 \pm $1013.5 \mathrm{pg} / \mathrm{ml}$ ) in uncomplicated TB patients subgroup and ranged from 3455 - $5900 \mathrm{pg} / \mathrm{ml}$. Statistically, the levels of MMP-9 in complicated TB patients were significantly higher than in uncomplicated TB patients $(\mathrm{P}<0.0001)$ (table 2, Figure 3).

Table 2: MMP-9 levels in serum samples of uncomplicated TB patients and subdivisions of complicated TB patients.

\begin{tabular}{|c|c|c|c|c|}
\hline & \multicolumn{4}{|c|}{ TB patients $(n=46)$} \\
\hline & \multicolumn{3}{|c|}{ Complicated cases $(n=33)$} & \multirow{2}{*}{$\begin{array}{l}\text { Uncomplicated } \\
\text { cases } \\
(n=13)\end{array}$} \\
\hline & $\begin{array}{l}\text { Pleural effusion } \\
(n=15)\end{array}$ & $\begin{array}{l}\text { Empyema } \\
(n=12)\end{array}$ & $\begin{array}{l}\text { Apical cavitation } \\
(n=6)\end{array}$ & \\
\hline $\begin{array}{l}\text { MMP-9 range } \\
(\mathrm{pg} / \mathrm{ml})\end{array}$ & $6350-6900$ & $7100-8400$ & $7000-8500$ & $3455-5900$ \\
\hline $\begin{array}{l}\text { Mean } \pm \text { SD } \\
(\mathrm{pg} / \mathrm{ml})\end{array}$ & $6625.5 \pm 199.17$ & $7819.2 \pm 424.1$ & $7625 \pm 560.1$ & $4884.5 \pm 1013.5$ \\
\hline F value & \multicolumn{4}{|l|}{53.162} \\
\hline
\end{tabular}




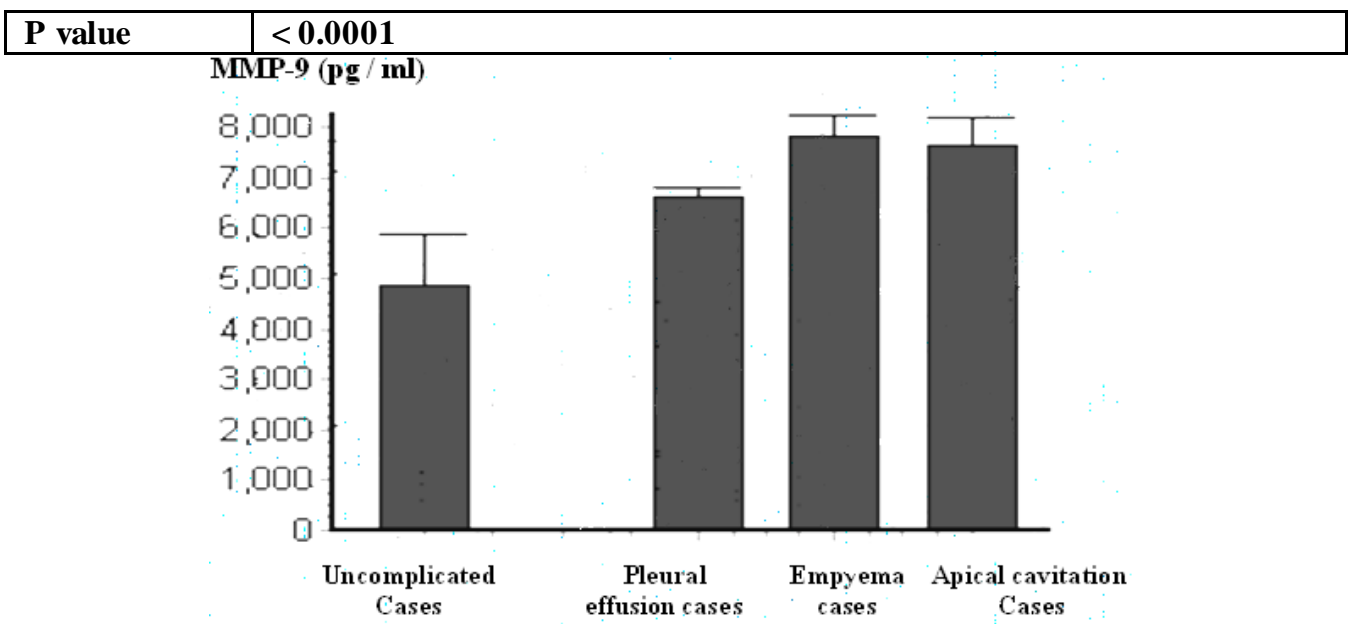

Fig. 3: MMP-9 levels in serum samples of uncomplicated TB patients and subdivisions of complicated TB patients.

\section{DISCUSSION}

The mechanism of MTB penetration into tissues is poorly understood but it is reasonable to assume that there is a contribution from proteases capable of disrupting the extracellular matrix of the pulmonary epithelium and the blood vessels $^{(23)}$. It appears that the collagen degrading activity of $M$. tuberculosis, which is also important for bacterial penetration in tissues, contributes to a disruption of ECM of the pulmonary epithelium and blood vessels ${ }^{(23)}$. MTB infection induces the expression of host MMPs which are capable of tissue degradation (17). So, the suggestion presented by Dannenberg ${ }^{(24)}$ That MTB itself is non-toxic and only the host reactions and release of MMPs destroy the lung tissues, seems rather doubtful. MMP-9 induction is elicited by the direct interaction between cell wall components of MTB bacilli and human monocytes and macrophages. MMP-9 could play important roles in the pathogenesis of tuberculosis (17). MMP-9 (gelatinase B) has been implicated in the pathogenesis of asthma $^{(25)}$, idiopathic pulmonary fibrosis (26), chronic obstructive pulmonary disease (COPD) ${ }^{(27)}$, and acute lung injury ${ }^{(28)}$.

In the present study, the results showed that, MMP-9 levels were significantly higher in tuberculosis patients than in healthy volunteers ( $\mathrm{P}$ $<0.0001$ ); this may be due to overexpression as a result of infection by a variety of cells including mononuclear phagocytes and stimulated neutrophils. This result is in agreement with a previous finding (15) which stated that MMP-9 levels are high in TB patients and the large number of infiltrating neutrophils may contribute to high levels of MMP-9, since neutrophils harbor preformed 
MMP-9 in their granules that can be readily released, also there are many lung cells can synthesize and release MMP-9. The elevation of MMP-9 levels was also observed by RiveraMarrero et al. after infection of cultured U937 human monocytes cells with an attenuated as well as a virulent strain of $M$. tuberculosis ${ }^{(17)}$.

In this study we observed also that MMP-9 levels are directly proportional with the severity of tuberculosis cases from uncomplicated cases to complicated cases; this may be due to existence of large number of acid fast bacilli. This result is in agreement with a previous finding (15) which stated that the influence of large bacterial loads in the tissues may also be one of the reasons for the high MMP-9 activity.

In conclusion, MMP-9 was presented in a high concentration in serum samples of patients with MTB comparing with its levels in serum samples of healthy volunteers due to overexpression by a variety of cells including mononuclear phagocytes and stimulated neutrophils. MMP-9 concentrations were increased with increasing the severity of the disease as measured in complicated and uncomplicated cases so; the evaluation of the serum levels of this enzyme may be helpful for estimating the activity of pulmonary tuberculosis.

\section{REFERENCES}

1. Tufariello J.M., Chan J., and Flynn J.L. (2003): Latent tuberculosis: mechanisms of the host and bacillus that contribute to persistent infection. Lancet Infect. Dis.; 3(9):578-90.
2. Means T.K., Wang S., Lein E, and et al. (1999): Human tolllike receptors mediate cellular activation by mycobact. Tuberculosis. J. Immunol.; 163: 3920-7.

3. Smith P.H.A., Jacobs R.F., and Wilson C.B. (1997): Immunology of childhood tuberculosis: A window on the ontogeny of cellular immunity. $J$. of Pediatrics: 131: 1.

4. Fulton S.A., Johnsen J.M., Wolf S.F., and et al. (1996): Interleukin-12 production by human monocytes infected with Mycobacterium tuberculosis: role of phagocytosis. Infect. immun., 64: 2523-31.

5. Shapiro S.D. (1998): Matrix metalloproteinase degradation of extracellular matrix: biological consequences. Curr. Op. Cell Biol.; 10: 602-08.

6. Woessner J.F. (1991): Matrix metalloproteinases and their inhibitors in connective tissue remodeling. FASEB J.; 5:214554.

7. Stetler W.G. (1996): Dynamics of matrix turnover during pathologic remodeling of the extracellular matrix. Am. J. Pathol.; 148:1345-50.

8. Nagase $H$, and Woessner J.F. (1999): Matrix metalloproteinases. J. Biol. Chem. 274:21491-4.

9. Baker A.H., Edwards, D.R., and Murphy G. (2002): Metalloproteinase inhibitors : Biological actions and therapeutic opportunities. J. Cell Sci.;115: 3719-27. 
10. Zucker S., Mirza H., Conner C.E, Lorenz A.F., Drews M.H., Bahou W.F., and Jesty J. (1998): Vascular endothelial growth factor induces tissue factor and matrix metalloproteinase production in endothelial cells: Conversion of prothrombin to thrombin results in progelatinase A activation and cell proliferation. Int. J. Cancer.; 75:780-786.

11. Hurewitz A.N., Zucker S., Mancuso P., Wu C.L., Dimassimo B., Lysik R.M., and Moutsiakis D. (1992): Human pleural effusions are rich in matrix metalloproteinases. Chest.; 102:1808-14.

12. Fickelberg O., Sommerfeld C.O., Wyser C., Tamm M., Reichenberger F., Bardin P.G., Soler M., Roth M., and Perruchoud A.P. (1997): MMP and TIMP expression pattern in pleural effusions of different origins. Am. J. Respir. Crit. Care Med.; 156:1987- 92.

13. Gordon S., Todd J., and Cohn Z.A. (1974): In vitro synthesis and secretion of lysozyme by mononuclear phagocytes. J. Exp. Med.; 139:1228-48.

14. Gordon S., and Cohn Z.A. (1978): Bacille Calmette-Guérin infection in the mouse. Regulation of macrophage plasminogen activator by $\mathrm{T}$ lymphocytes and specific antigen. J. Exp. Med.; 147:1175-88.

15. Quiding J.M., Smith D.A., and Bancroft G.J. (2001): Production of matrix metalloproteinases in response to mycobacterial infection. Infect. Immun. 69:5661-70.

16. Rivera-Marrero C.A., Schuyler W., Roser S., Ritzenthaler J.D., Newburn S.A., and Roman J. (2002): M. tuberculosis induction of matrix metalloproteinase-9: The role of mannose and receptor-mediated mechanisms. Am. J. Physiol. Lung Cell Mol. Physiol.; 282:L546-L55.

17. Rivera-Marrero C.A., Schuyler W., Roser S. and Roman J. (2000): Induction of MMP-9 mediated gelatinolytic activity in human monocytes cells by cell wall components of Mycobacterium tuberculosis. Microbial Pathogenesis. 29: 231-44

18. Chang J.C., Wysocki A., Tchou-Wong K.M., Moskovitz N., Zhang Y., and Rom W.N. (1996): Effect of Mycobacterium tuberculosis and its components on macrophages and the release of matrix metalloproteinases. Thorax; 51: 306-11.

19. Jenkins P.A. (1992): The laboratory diagnosis of mycobacterial disease. Common. Dis. Respire. CDR. Rev.; 2(9): 101.

20. Nagase H. (1997): Activation mechanisms of matrix metalloproteinases. Biol. Chem.; 378(3-4): 151-60..

21. Borkakoti N. (1998): Matrix metalloproteases: variations on a theme. Progress in Biophysics and Mol. Biol.; 70(1): 73-94.

22. Giambernardi T.A., and et al. (1998): Overview of matrix metalloproteinase expression in 
cultured human cells. Matrix Biol.; 16(8): 483-96.

23. Massó F., Paéz A., Varela E, Diaz de León L., and Zenteno E. (1999): Collagen degrading activity associated with Mycobacterium species. Thorax.; 54: 439-41.

24. Dannenberg A.M. (1994): Roles of cytotoxic delayed-type hypersensitivity and macrophageactivating cell-mediated immunity in the pathogenesis of tuberculosis. Immunobiol.; 191: 461-73.

25. Cataldo D., Munaut C., Noel A., Frankenne F., Bartsch P., Foidart J.M., and et al. (2000): MMP-2- and MMP-9-linked gelatinolytic activity in the sputum from patients with asthma and chronic obstructive pulmonary disease. Int. Arch. Allergy Immunol.; 123(3):25967.
26. Fukuda Y., Ishizaki M., Kudoh S., Kitaichi M., and Yamanaka N. (1998): Localization of matrix metalloproteinases $-1,-2$, and -9 and tissue inhibitor of metalloproteinase- 2 in interstitial lung diseases. Lab. Invest.; 78(6):687-98.

27. Russell R.E, Culpitt S.V., DeMatos C., Donnelly L., Smith M., Wiggins J., and et al. (2002): Release and activity of matrix metalloproteinase-9 and tissue inhibitor of metalloproteinase- 1 by alveolar macrophages from patients with chronic obstructive pulmonary disease. Am. J. Respir. Cell Mol. Biol. 26(5):602-09.

28. Michele Y.F., Amit G., Yao L., Margaret W.J., Edwin B., and Clancy J.P. (2009): Matrix Metalloproteinase Activity in Pediatric Acute Lung Injury. Int. J. Med. Sci.; 6 (1):9-17. 


\section{تعيين الأنزيم ألبروتيني الفلزي القالبي رقم 9 في المرضى المصريين المصابين بعصويات الدرن الرئوي في المئر}

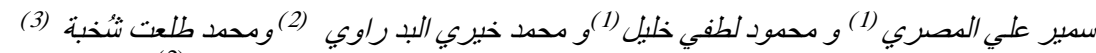

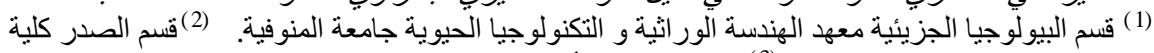
الطب جامعة المنصورة. (3) الهيئة العامة للتأمين الصحية لئريا عيادة ابن سينا المحلة الكبرى.

يهدف هذا البحث : إلى در اسة مستوى الأنزيمات البروتينية الفلزية القالبية و خاصة الأنزيم الفلزي القالبي

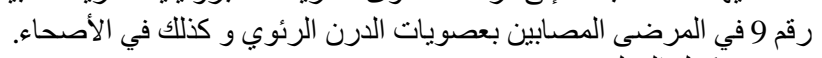

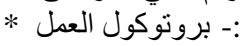

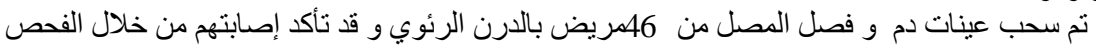

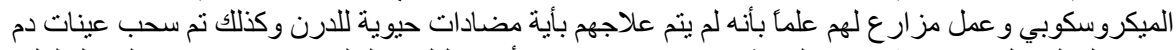

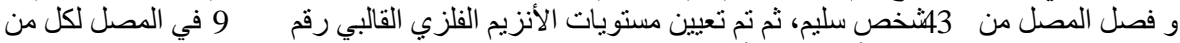
المرضى المصابين بالدرن و الأشخاص الأصحاء باستخدام طريقة الإليزا.

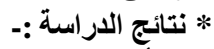

أظهرت نتائج مرضى الدرن زيادة ذات دلالة إحصائية في مستوي الأنزيم الفلزي القالبي رقم

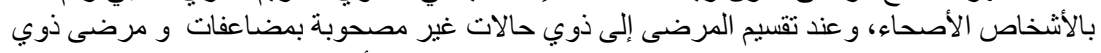

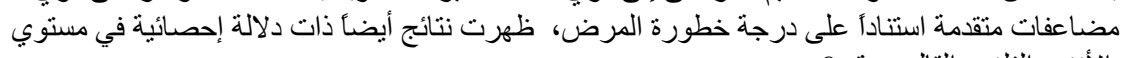

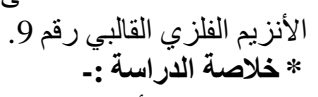

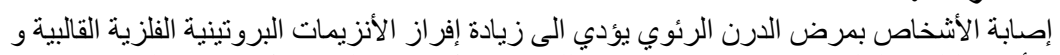

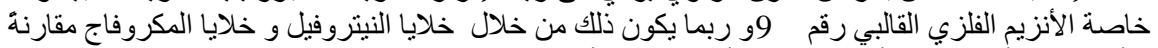

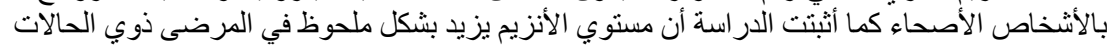

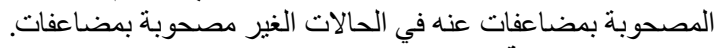

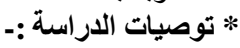

قد يفيد استخدام قياس مستوي الأنزيم الفلزي القالبي رقم 9في تقدير نشاط عصويات الدرن الرئوي في المرضى المصابين بها 